Article

\title{
Towards Place-Based Research to Support Social-Ecological Stewardship
}

\author{
Jessica Cockburn ${ }^{1, *}(\mathbb{D})$, Georgina Cundill ${ }^{1,2}$, Sheona Shackleton ${ }^{1}$ and Mathieu Rouget ${ }^{3,4}$ \\ 1 Department of Environmental Science, Rhodes University, Grahamstown 6139, South Africa; \\ gkemp@idrc.ca (G.C.); sheona.shackleton@gmail.com (S.S.) \\ 2 International Development Research Centre, Ottawa, ON K1P 0B2, Canada \\ 3 UMR PVBMT, CIRAD, St Pierre, 97410La Réunion, France; mathieu.rouget@cirad.fr \\ 4 School of Agriculture, Earth and Environmental Sciences, University of KwaZulu-Natal, \\ Scottsville 3201, South Africa \\ * Correspondence: jessicacockburn@gmail.com; Tel.: +27-72-102-2875
}

Received: 4 April 2018; Accepted: 20 April 2018; Published: 4 May 2018

\begin{abstract}
Concerns about ecological degradation and social inequalities have prompted increasing calls for stewardship in the social-ecological systems and sustainability science literature. However, how can the ideals of stewardship be realised in practice? The links between the theory and practice of stewardship are under-developed, and research to support place-based stewardship practice is limited. We therefore bring together complementary perspectives to guide research on place-based stewardship practice in the context of multifunctional landscapes. We unpack and synthesise literature on stewardship, landscapes, and collaboration for natural resource management, and highlight the ways in which the pathways approach can deepen research on collaboration and stewardship practice. We propose landscapes as a suitable level of analysis and action for stewardship. Since all landscapes are multifunctional, we argue that collaboration among multiple stakeholders is a necessary focus of such research. Our analysis reveals that existing theory on collaboration could be deepened by further research into the agency of individual human actors, the complex social-relational dynamics among actors, and the situatedness of actors within the social-ecological context. These factors mediate collaborative processes, and a better understanding of them is needed to support place-based stewardship practice. To this end, the pathways approach offers a waymark to advance research on collaboration, particularly in the complex, contested social-ecological systems that tend to characterize multifunctional landscapes.
\end{abstract}

Keywords: collaboration; ecosystem stewardship; human agency; multifunctional landscapes; multiple stakeholders; pathways approach; situated research; social-ecological systems; sustainability science

\section{Introduction}

The concept of stewardship has recently seen a rise in popularity in the literature on resilience and sustainable social-ecological systems (SES) [1-3], including high-level calls for "earth stewardship" [4] and "planetary stewardship" [5]. This increasing interest in and use of the idea of stewardship in the sustainability discourse has likely arisen from the growing recognition worldwide of the coupled challenges of rapidly increasing ecological degradation and social inequalities [6-8]. These challenges are exacerbated by rapid global change characterised by a human-dominated earth system termed the 'Anthropocene' [5]. In response to these concerns, stewardship has been widely used as a banner calling for more responsible and ethical engagement by humans with their fellow humans and the planet. However, while the concept of stewardship is widely used and intuitively understood, it is also confusing and contested $[9,10]$. If stewardship is considered a significant part of the solution to 
ecosystem degradation and social inequality, and a key to sustainability of SES, we need to ask: how can it be better understood and more importantly, how can it be achieved in practice? Theoretical insights on stewardship are somewhat disparate $[11,12]$ and there are few conceptual frameworks to support the research and practice of stewardship, although strides are being made in this regard (see Bennett et al. [13]). As a result, the links between the theory and practice of stewardship remain under-developed [11,14], and the spatial (and temporal) scales at which social-ecological stewardship outcomes can be achieved in practice require further investigation. Although more place-based, contextualised research at landscape level is needed [15], there is limited conceptual guidance on the necessary building blocks of such research.

Landscapes are examples of SES, which can offer an appropriate unit of analysis for investigating stewardship in practice [16,17]. Landscapes can be seen as multifunctional and heterogenous terrestrial regions which bring together, in a particular place, the 'many multiples' (stakeholders, ecosystem services, land uses, institutions and organisations, and scales of action and decision-making) which characterise SES and pose challenges to management and governance $[18,19]$. If we are to bring about place-based stewardship practice in landscapes in a way that accounts for the multiple functions such landscapes perform, then of necessity we should consider collaboration among the multiple people who live in, work in, utilise, manage, and govern the landscape [20-22]. Collaboration among diverse landscape stakeholders, therefore, becomes a key concern for studying stewardship in practice. However, there is a need to deepen existing research on collaboration for stewardship to better account for the way in which individual human agency, complex social-relational dynamics among actors, and the situatedness of actors within the social-ecological context mediate collaborative processes.

In this paper we bring together complementary perspectives that can guide research on place-based stewardship practice in the context of multifunctional landscapes. We do this by drawing on and unpacking literature on stewardship, landscapes, and collaboration for natural resource management. We build on this synthesis by highlighting the ways in which the pathways approach [23] can deepen research on collaboration and stewardship practice. The value of our contribution lies in the bringing-together of these different perspectives which can support place-based stewardship research and practice in new ways. We begin by exploring why stewardship is important in sustainability research generally, before arguing for the importance of a research focus on stewardship practice. We go on to make the case for landscapes as a suitable arena for studying and supporting stewardship practice. In so doing, we expose the reality that collaboration must be a core concern for scholars and practitioners interested in pursuing place-based stewardship at landscape level. We then review existing approaches to collaboration in the natural resource management literature. Building on this, we suggest the pathways approach as a theoretical waymark to further support research into, and practice of, social-ecological stewardship in multifunctional landscapes.

\section{Stewardship for Sustainable Social-Ecological Systems}

\subsection{What is Stewardship?}

The term 'stewardship' is appealing in that it has an ethical basis and carries with it a moral imperative. By practicing stewardship, humans manage ecosystems out of moral concern $[9,11,24]$. Thus, it is "a concept which directs individual and collective action" [25] (p. 4). Stewardship is a particular role played by humans [9] and thus the agency of individual stewards, or of stewards acting collectively, is brought into focus $[25,26]$ and must be considered when studying stewardship in practice [27]. The origins and history of the term in western, Christian society has raised concerns about its applicability for a plural society with diverse world views and understandings, and this has led some researchers to question the global suitability of the term $[10,28,29]$. Yet, its continued, and in fact increasing $[12,13]$ use in multiple settings seems to speak for its applicability and usefulness, even in secular contexts [11,29]. Furthermore, these concerns and critiques highlight the importance of investigating the underlying political and ideological aspects of stewardship [12]. This can be done 
by reflectively asking questions like "what is my ideology of stewardship and how does it shape the research and/or policy design?" [12] (p. 368).

There is no unified definition of the concept of stewardship in the sustainability sciences and SES literature. In most recent studies seeking to define or conceptualise stewardship, multiple meanings and underlying ideologies have been identified, both theoretically [12,13] and empirically [27]. Understanding of the concept in the environmental sense has changed over time. These changes have mirrored changes in conceptualisations of the relationships between humans and nature $[10,30]$. For example, recent interpretations of stewardship exemplify the global sustainability discourse $[9,11]$ and signify a shift towards more integrated and systemic understandings of the relationships between humans and nature. On the other hand, previous interpretations were based on a more dichotomous relationship of humans either having dominion over nature [28], or being protectors of nature [30]. The most recent conceptualisations of stewardship emerge from two distinct perspectives, namely environmental stewardship and ecosystem stewardship (Table 1).

Environmental stewardship [9] expresses the classic and intuitive understanding of the concept which exemplifies the moral-ethical basis of the concept (Table 1). In response to critiques of the concept, Welchman [9] builds on the older definition of environmental stewardship proposed by Worrell and Appleby [11] to incorporate two important features in order to align stewardship with changing societal norms and values. These two features are:

1. "explicit recognition of the irreducible pluralism of the competing 'interests' in question"; and

2. because stewardship is a role played by someone "its moral justification is a function of its overall consistency with our common moral norms, including norms of justice, tolerance, and equity in the distribution of social benefits and burdens" [9] (p. 303).

This definition is broadly applicable across the various bodies of environmental literature in which the concept is used. It is echoed for example in the recent definition of local environmental stewardship proposed by Bennett et al. [13] (p. 1) as "the actions taken by individuals, groups or networks of actors, with various motivations and levels of capacity, to protect, care for or responsibly use the environment in pursuit of environmental and/or social outcomes in diverse social-ecological contexts."

Table 1. Definitions of stewardship relevant to sustainable social-ecological systems.

\begin{tabular}{cl}
\hline Term & $\begin{array}{c}\text { Definition } \\
\text { "Environmental stewardship is the responsible management of human activity affecting the natural environment to } \\
\text { ensure the conservation and preservation of natural resources and values for the sake of future generations of human } \\
\text { stewardship } \\
\text { and other life on the planet, together with the acceptance of significant answerability for one's conduct to society" [9] } \\
\text { (p. 303). "The goal of environmental stewardship is to manage human behaviour in order to restore or maintain the } \\
\text { integrity of environmental systems and their services to human and other communities of life." [31] (p. 130) }\end{array}$ \\
\hline $\begin{array}{c}\text { Ecosystem } \\
\text { stewardship }\end{array}$ & $\begin{array}{l}\text { Ecosystem stewardship is "a strategy to respond to and shape social-ecological systems under conditions of } \\
\text { uncertainty and change to sustain the supply and opportunities for use of ecosystem services to support human } \\
\text { well-being" [1] (p. 241), or "the active shaping of pathways of social and ecological change for the benefit of } \\
\text { ecosystems and society" [32] (p. 40). }\end{array}$ \\
\hline $\begin{array}{c}\text { Social-ecological } \\
\text { stewardship }\end{array}$ & $\begin{array}{l}\text { A general term which is starting to appear in the literature but is not yet clearly defined [15,33]. We propose the } \\
\text { following working definition: "Social-ecological stewardship is the ethical and responsible interaction of humans } \\
\text { with social-ecological systems to sustain the supply of diverse ecosystem services and values for the sake of current } \\
\text { and future generations of humans and other life on the planet". }\end{array}$ \\
\hline
\end{tabular}

Ecosystem stewardship (Table 1) is aligned with an SES approach, with resilience thinking, and is framed in the context of rapid global change [1]. According to Chapin [1], ecosystem stewardship is an action-oriented framework to bring about better management and governance of complex social-ecological systems. Ecosystem stewardship is a resource management paradigm proposed to guide human interactions with SES [33] which builds and extends the principles of ecosystem management, rather than a definition per se, which is what Welchman [9] provides. Thus, the concept of ecosystem stewardship is a specific application of the broader concept of stewardship and departs quite significantly from other environmental literature on stewardship. 
The term social-ecological stewardship (Table 1) is proposed here as a useful 'middle ground' term which recognises the value of a SES framing, whilst also incorporating the moral-ethical basis and enduring understanding of the term stewardship offered by environmental stewardship [9]. We define it as the ethical and responsible interaction of humans with social-ecological systems to sustain the supply of diverse ecosystem services and values for the sake of current and future generations of humans and other life on the planet. For the remainder of the article, we will use the term stewardship to imply the working definition of social-ecological stewardship proposed here.

The concept of stewardship is put into practice in a diversity of ways. This includes initiatives that are policy-driven, such as private land conservation approaches, agri-environmental schemes, and watershed or catchment management initiatives. There is also a wide range of approaches to stewardship practice purported to be more bottom-up, for example community-based natural resource management initiatives, and integrated landscape approaches. Further details on the practical applications of stewardship can be found in, amongst others, Carr [34], Bennett et al. [13], Barendse et al. [14] and Bieling and Plieninger [17].

\subsection{What Does it Mean to Study Stewardship Practice in Social-Ecological Systems?}

There has been a rise in interest in studying human and natural systems in a more integrated way, leading to a proliferation of frameworks in different fields and disciplines [35]. One of these frameworks is the social-ecological systems (SES) framework. It is within the rapidly growing field of research applying the SES framework that the concept of stewardship has recently received increasing attention.

The SES framework has its origins in ecology and arose out of the development of resilience theory for analysing and managing ecosystems adaptively [36]. The concept of social-ecological systems is used to describe an integrated perspective of humans-in-nature [2,37]. Resilience is a key characteristic of SES [38] and is understood as the capacity of a system to absorb disturbance and re-organise while undergoing change, so as to still retain essentially the same function, structure, identity, and feedbacks [39]. The boundary between the social and the ecological in SES is considered artificial and arbitrary [37]. The social refers to diverse facets of the human dimensions of systems including economic, political, technological, and cultural facets. The ecological refers to the biosphere, i.e., the global ecological system. This integrates all living beings, including humans, and the dynamic interactions between all beings with the dynamics of the earth system including the atmosphere, water cycles, and biogeochemical cycles. At its core the concept of social-ecological systems posits that human systems are embedded in, and entirely dependent on, the biosphere [2].

The SES perspective seeks to shift policies and practices from a mode of controlling change in systems which were assumed to be stable, to a mode of managing the resilience of dynamic social-ecological systems to respond and adapt to change [38]. The concept of social-ecological systems has been used to motivate for global policies and practices in support of sustainability that place more emphasis on a biosphere-based approach to development which recognises that social and economic systems are embedded in, and entirely dependent on, ecological systems [2]. This is echoed in the global calls for stewardship of the biosphere in support of social-ecological sustainability for current and future generations described above $[1,5,40]$. The increasing calls for stewardship globally-and the recognition that ecological destruction and rising social inequalities are not abating [5,7,41]—suggest that the ideals of stewardship are not being realised in practice. Therefore, studying stewardship practice within the SES framing raises questions about how to support the ethical and responsible interaction of humans within dynamic social-ecological systems towards interlinked social-ecological sustainability outcomes that benefit the planet as a whole.

To achieve these interlinked outcomes, stewardship needs to follow safe and just pathways to sustainability, taking into account issues of power, politics, and contestation around the benefits of ecosystem services [6,41]. Raworth [42] (p. 44) proposes the doughnut model as a compass to guide efforts towards social-ecological sustainability which addresses these issues. The doughnut model is composed of an outer ring of planetary boundaries called the ecological ceiling which should not 
be crossed to maintain the earth system in a safe state [43]. These boundaries include biophysical processes such as climate change, air pollution, and biodiversity loss; concerns which have long been associated as ideal outcomes of effective stewardship [29]. The inner ring of the doughnut is the social foundation below which lie human shortfalls in well-being related for example to health, education, social equity, and political voice. These social concerns have only recently emerged in the stewardship discourse [2,9]. The space between the outer and inner ring of the doughnut is "a safe and just space for humanity to thrive in" [6] (p. 4). Therefore, efforts towards social-ecological stewardship should be about navigating pathways towards a safe and just space for humanity which account for both the ecological ceiling (pathways which are safe), and the social foundation (pathways which are just) of the doughnut model.

Until now, the literature on stewardship in social-ecological systems and sustainability science has been dominated by conceptual and theoretical discussions [1,2,12,13]. We agree with Bennett et al. [13] that we now need to move toward place-based empirical experimentation and active learning about the practice of stewardship in social-ecological systems in order to support realisation of stewardship ideals. The following question thus arises: how does one move from the theory of stewardship to practice, in the context of complex SES and rapid global change? And, in recognition of the interlinked nature of SES how can stewardship actions and practice (1) lead to positive ecological and social outcomes, and (2) address concerns about social justice in terms of shared ecosystem services benefits [9,13]? Bennett et al. [13] pose similar questions and provide a conceptual framework to guide analysis and practice of stewardship in various contexts at the local level. Here, we take this work further in the specific context of multifunctional landscapes, which offer a particularly challenging arena for investigating stewardship practice. Multifunctional landscapes show parallels of many global stewardship challenges such as conflict and contestation around benefits from ecosystem services, trade-offs in the provision of multiple ecosystem services, and the need to address questions of social justice and equity whilst sustainably utilising ecosystem services [44,45]. In the following section, we argue for multifunctional landscapes as suitable place-based arenas for investigating stewardship practice using a social-ecological system framing.

\section{Investigating Stewardship Practice in Multifunctional Landscapes}

Above we proposed that landscapes are the most appropriate level of analysis to better understand stewardship in practice. In this section we further refine this claim, based on two key arguments. Firstly, managing landscapes for multifunctionality can lead to more equitable and sustainable benefits. Secondly, landscapes offer the appropriate ecological and institutional level for analysis and action to support social-ecological stewardship in practice. Each of these arguments are elaborated upon in turn below. First, we briefly introduce the concept of landscapes.

\subsection{What Are Landscapes?}

The concept of landscapes has a multitude of definitions and interpretations and has arisen as a spatial focus across a wide range of fields and disciplines [17,20,46-48]. Angelstam et al. [16] (p. 131) suggest that the various interpretations of the term 'landscape' can be analysed according to four distinct categories of meaning:

1. biophysical interpretations i.e., landscape as a purely natural phenomenon;

2. anthropogenic interpretations i.e., landscape as nature with human artefacts;

3. intangible interpretations i.e., landscape as a cognitive representation of a space, socio-economic interpretations and landscape as socially organised space; and

4. coupled social-ecological interpretation i.e., landscape as a totality including both material natural and cultural dimensions as well as spiritual phenomena.

Whilst recognising that all these are valid understandings of landscapes, in this article we align ourselves with the fourth category proposed by Angelstam et al. [16]. Accordingly, we suggest that 
landscapes are place-based social-ecological systems that emerge from the interactions between people, through their values and institutions, with land-based ecosystems and the natural resources they generate [22,49]. The boundaries of landscapes are variously defined, for example by catchment boundaries, the boundaries of an area with a unique or coherent character, or as a sub-unit of a natural or jurisdictional region [50].

Landscapes generate a flow of ecosystem services which underpin human well-being, including provisioning, regulating, supporting, and cultural ecosystem services [8,51]. A higher diversity of ecosystem services in the landscape is an indicator of higher multifunctionality and often correlates with higher levels of regulating and cultural ecosystem services and lower crop production intensities [19,52] (Figure 1).

In many rural landscapes, agricultural production is one of the most important human uses of the landscape, for both commercial and subsistence purposes [48,53,54]. Agricultural production mostly increases provisioning ecosystem services in a landscape, whilst altering the structure and function of ecosystems, which can result in reduced production of regulating and cultural ecosystem services [55] (Figure 1). Yet, functioning, healthy ecosystems and biodiversity are important for the long-term sustainability of agriculture, and agriculture is underpinned by a variety of ecosystem services including pest control, pollination, water provision, and soil formation [56,57].

\subsection{Managing Landscapes for Multifunctionality Can Enhance Sustainability and Equity}

All landscapes are inherently multifunctional [45]; however, intensive agricultural production has led to monoculture cropping [58], over-simplification of landscape structure and function [55] (Figure 1), and a loss of resilience in agricultural landscapes [57,59]. Figure 1 illustrates one understanding of multifunctionality, based on the diversity of ecosystem services delivered. This suggests that multifunctionality is usually higher in near-natural or natural landscapes (b) than in intensively farmed and simplified agricultural landscapes (a), and that managing for multifunctionality can lead to ecosystem services being produced in more balanced proportions (c) leading to more sustainable landscapes [21]. This is not to say that multifunctionality cannot be high in agricultural landscapes, but rather that by explicitly managing such landscapes for multifunctionality (and not maximising one type of land use as in monoculture cropping), multiple ecological, social, and cultural values of the landscape can be enhanced to benefit a diversity of stakeholders [60,61].

Therefore, whilst agriculture plays a key role in the production of important resources for human well-being, it also has significant negative environmental impacts such as degradation of soil and water resources, loss of biodiversity [62,63], and human-induced climate change [64]. Consequently, there is a long-standing conflict between agricultural and environmental outcomes in landscapes [65]. Achieving a balance in the production of a diversity of ecosystem services in landscapes which include agricultural activities is a challenge [55], and certainly one that will be encountered by efforts in fostering stewardship among diverse stakeholders across the landscape.

The concept of 'multifunctional landscapes' makes explicit the need to address multiple functions, for example ecological, agricultural, and social functions, expressed as a diversity of ecosystem services in a given landscape $[21,22,45]$. Different stakeholders in a landscape will tend to value different functions or benefits from the landscape, often resulting in contestation. However shared associations and values in the landscape, sometimes expressed as a shared sense of place, can also be a driver of collective stewardship [61,66,67]. Managing or stewarding agricultural landscapes with an emphasis on multifunctionality offers opportunities to identify and optimise synergies among multiple ecosystem services [55] (Figure 1). Furthermore, place-based stewardship of multifunctional landscapes holds the potential to address the concurrent goals of ecological sustainability and human well-being, rather than favouring one over the other [68]. 
(a) Intensively farmed, simplified agricultural landscapes
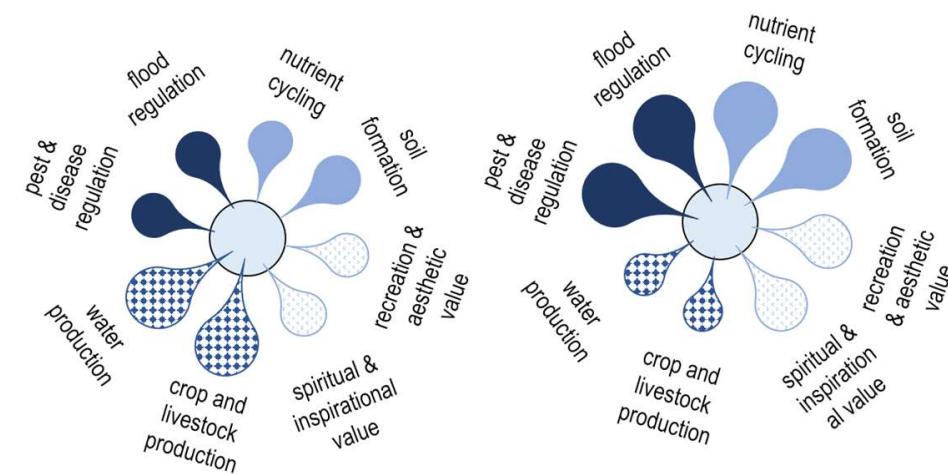

(b) Near-natural landscapes

(c) Multifunctional landscapes

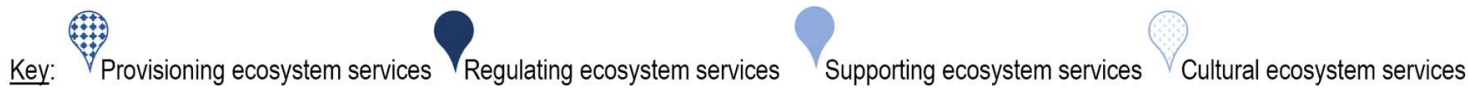

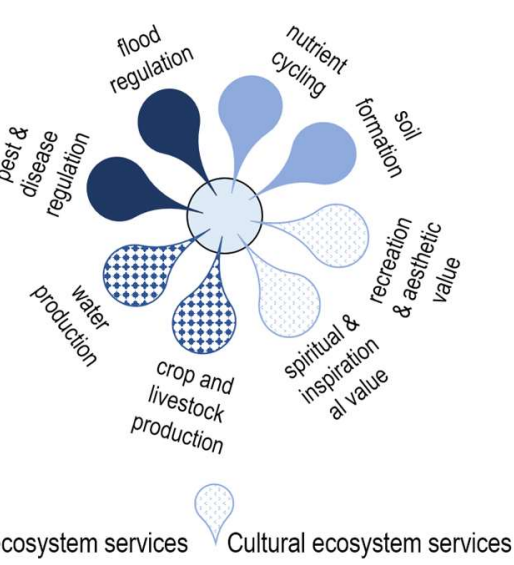

Figure 1. Landscapes provide a diversity of ecosystem services, which are utilised in different proportions according to the nature of the landscape $((\mathbf{a}-\mathbf{c}))$. A higher diversity of ecosystem services suggests higher levels of multifunctionality (Adapted from Gordon et al. [55]; Raudsepp-Hearne et al. [52]).

Therefore, in order to balance the delivery of ecosystem services and benefits for multiple stakeholders, and to address the conflict between agriculture and other land uses, landscapes need to be explicitly managed for multifunctionality $[19,63]$. This can lead to enhanced sustainability of the landscape [21] and more equitable sharing of benefits flowing from ecosystem services [45].

\subsection{Landscapes Offer an Appropriate Arena for Social-Ecological Stewardship Practice}

Since many ecological processes in landscapes operate at levels beyond the individual farm or village level, approaches are needed to manage and govern production and utilisation of ecosystem services in landscapes at the appropriate spatial level $[17,50]$. These ecological processes include interactions between animal species such as wildlife, pests, and pollinators [69] as well as water provision and purification, soil retention, and climate regulation [56]. A variety of environmental management challenges also operate at larger levels and include wild fires, flooding, climate change, disease, and invasive species [70]. The spatial configuration of ecosystems in agricultural landscapes is critical to the supply of many ecosystem services, which requires that farms be managed, or stewarded, in a coordinated way at landscape level rather than as individual units [71,72].

We use the term 'level' to denote landscapes as a piece of land located along a spatial scale [73]. The 'landscape level' is defined as the level along a spatial scale "above the field, farm- and local scale; it can be a catchment, an area of coherent landscape character or a sub-unit of a natural region" [50] (p. 244). The landscape is the primary level at which the actions and decisions of individual farmers, or localised resource-user groups, intersect with those of other resource users, stakeholders, and decision-makers [74]. It is at this level that individuals interact collaboratively with others and with broader institutional structures and processes, i.e., landscapes are the level at which individual stewards interact with the broader social-ecological system [67]. Furthermore, landscapes offer an analytical and practical space to explore the integrated challenges of ecological degradation and equitable distribution of the benefits of ecosystem services in practice [6,41], i.e., for navigating pathways between social and planetary boundaries. They are complex, place-based systems of many multiples. They produce multiple ecosystem services, function at multiple levels and scales, incorporate multiple issues of interest and concern, are subject to multiple drivers of change, and include multiple stakeholder voices and values [18,45]. Consequently, achieving stewardship across landscapes in a sustainable and equitable manner requires trade-offs between actors (social trade-offs) and different ecosystem services (ecological trade-offs) [75]. Social-ecological trade-offs 
are more visible at the landscape level compared to the individual farm level, and stewarding the landscape to address these trade-offs thus becomes a collective responsibility at the landscape level [68]. The landscape level therefore offers an opportunity to work beyond the individual farm or village level, by fostering collaboration among multiple stakeholders, to address social-ecological sustainability challenges in an integrated and equitable manner.

Landscapes are increasingly recognised as an appropriate arena for investigating and practicing stewardship [17]. Here we build on the recent work in this regard and respond to calls by Buck et al. [76] and Penker [60] for greater attention to be paid to the practical and conceptual challenges of collaborative stewardship efforts. We do so by providing an overarching view of existing theory on collaboration for natural resource management, and by arguing for the application of the pathways approach to advance and deepen our analysis of collaboration in complex multifunctional landscapes in support of place-based stewardship practice.

\section{Collaboration Is a Necessary Focus for Stewardship Research and Practice in Landscapes}

Since all landscapes are multifunctional and offer a suitable level of analysis and action, understanding how to support collaboration becomes a core concern for researchers interested in understanding stewardship practice $[19,50,60,76]$. We use Gray's [77] (p. 912) definition of collaboration: "The pooling of appreciations and/or tangible resources, e.g., information, money, labor, etc., by two or more stakeholders, to solve a set of problems which neither can solve individually." The topic of collaboration is by no means a new one in the literature on natural resource and landscape management $[60,67,76,78-80]$. Worldwide, efforts to devolve or share control, power, and management responsibility for natural resources to local resource users and owners has resulted in a wealth of literature on collaboration and collective action for natural resource management. Moreover, in a variety of contexts with limited government intervention or control, local people have been managing natural resources collectively for a long time [81,82].

Despite significant attention being paid to the notion, collaboration must not be viewed as a panacea to solve all natural resource management problems, as it can come at a cost, and it should not be viewed as an end in itself $[79,83]$. Rather, here we consider collaboration as a necessary feature of landscape level stewardship, since it has the potential to "enhance people's understanding, narrow the range of disagreements, build concurrence about necessary direction, and produce on-the-ground environmental improvements" [79] (p. xvi), and is essential for sustainable delivery of ecosystem services which operate at landscape-level. Collaborative processes in support of social-ecological stewardship which focus on dialogue and negotiation among multiple stakeholders offer the opportunity to address concerns about equitable access to the benefits of natural resources or ecosystem services, and sharing the costs of stewardship in landscapes $[34,79,84]$.

Collaboration is usually a consensus-based approach to management or governance which involves a wide range of stakeholders in an on-going manner [70,85]. Collaborative initiatives involve local resource users in a collective process of actively and intentionally taking responsibility and care of natural resources with which they interact, to realise the ideals of stewardship in practice. Beneficial social and ecological outcomes are likely to be fostered through committed participation by local citizens [86], and through good quality facilitation of social learning processes among diverse stakeholder groups [34,47]. However, collaboration and learning do not guarantee such outcomes, and collaboration can be difficult $[34,78,79,83]$. Collaboration in contested contexts, where there are concerns about equitable access to the benefits of ecosystem services, might in fact not be possible at all, or might lead to conflict as power imbalances and social injustice become apparent [87].

The literature on collaboration for natural resource or ecosystem management can be grouped into seven over-arching bodies (Table 2): common pool resource management (CPRM), community-based natural resource management (CBNRM), collaborative natural resource management (CNRM), various collaborative approaches to forest management in the tropics (collaborative forest approaches), 
co-management and adaptive co-management (CM \& ACM), integrated landscape approaches (ILA), and finally, a new emerging field which we label 'collaboration in complex, contested contexts' (CCCC).

These bodies of literature differ in a number of ways, primarily by the extent of multifunctionality they consider, i.e., the nature of the resource or ecosystem around which stakeholders are collaborating, as well as by the extent of collaborative complexity, i.e., the nature and diversity of collaborating stakeholders and level of spatial scale at which they are expected to collaborate (Table 2, Figure 2). The extent of multifunctionality refers to the number and complexity of resource systems (e.g., resource types, land uses, diversity of ecosystem services (both tangible and intangible)) and spatial level or scale. Furthermore, the concept of multifunctionality includes recognition of landscapes as plural social constructs reflecting history, culture, values and identity [67]. There is no obvious body of literature which explicitly looks at collaboration for stewardship in multifunctional landscapes; however, the diagram in Figure 2 indicates increasing applicability of the seven bodies of literature (from bottom left towards top right of the diagram), with the ILA and CCCC literature being most applicable.

In general, the literature at the bottom left of the diagram in Figure 2 is older and has a more established body of theoretical and empirical research, whereas the literature towards the top right is more recent and less established (Figure 2). Not only does the literature on ILA and CCCC account better for multifunctionality and complexity of the collaborative context in landscapes than the older literature, but ILA and CCCC also demonstrate recognition of landscapes as social constructs in which history, culture, and values play an important role in mediating people's agency and their interactions with one another and with the broader social-ecological system [44,67].

However, both ILA and CCCC are relatively recent bodies of literature (although ILA builds on the older integrated natural resource management [74]) and as such have yet to develop conceptual and theoretical depth, particularly in how they deal with the nuanced challenges of collaboration among diverse stakeholders in complex SES, and many questions around collaboration remain open [88,89]. For example, Penker [60], writing from an ILA perspective, points out that CPRM theory has been widely used to inform analysis of collaboration for stewardship in landscapes, but that the details within each of the principles need further work in the context of complex, multistakeholder landscape processes. Similarly, recognising that partnerships and collaboration for stewardship of landscapes are complex, dynamic social processes, Buck et al. [76] call for closer attention to be paid to building collaborative capacity (for example through facilitation tools and training) amongst the multiple cross-sectoral stakeholders expected to work together. Bieling and Plieninger [61] (p. 375) synthesise the challenges of collaboration and co-ordination in landscape approaches. In doing so, they pose the following as some of the most pressing, unresolved questions for the science and practice of landscape stewardship "... how can such intersectoral co-ordination be achieved and state, market and civil society be brought together? What are the enabling or favouring conditions for successful arrangements?" Furthermore, despite much optimistic academic rhetoric, the ability of ILA to reach the ideals of integrated social and environmental challenges and effectively address the trade-offs between agriculture and other land uses has been questioned [88,90] (but, see Bieling and Plieninger [17] for some recent examples of success in this regard).

The literature on collaborative forest approaches (Table 2: '4. Collaborative forest approaches') has a strong policy and practice focus and much of the work is published as grey literature. It is thus a rather disparate body of work. It has seen less cohesive theoretical development than other literatures on collaboration (in contrast to CPRM, CM, and ACM for example). Therefore, although it may contribute important practical lessons on collaboration in complex contexts (as it draws on experiences in complex, multifunctional forest landscapes mostly in the tropics), its potential contribution to theoretical questions regarding collaboration is somewhat limited (Figure 2). 
Table 2. Bodies of literature relevant to studying collaboration for stewardship in multifunctional landscapes. The boundaries between these bodies of literature are not entirely distinct and there is some overlap. They are clearly separated in this table to enable discussion.

\begin{tabular}{|c|c|c|c|c|}
\hline $\begin{array}{c}\text { Body of Literature and } \\
\text { Antecedents }\end{array}$ & Nature of Resource & $\begin{array}{l}\text { Nature and Diversity } \\
\text { of Collaborating } \\
\text { Stakeholders }\end{array}$ & $\begin{array}{l}\text { Main Limitations Relevant to } \\
\text { Studying Collaboration in } \\
\text { Multifunctional Landscapes }\end{array}$ & $\begin{array}{l}\text { Further Reading } \\
\text { and Case Studies }\end{array}$ \\
\hline $\begin{array}{l}\text { 1. Common Pool Resource } \\
\text { management (CPRM) [81,91]. } \\
\text { Draws on institutional } \\
\text { analysis and game theory. } \\
\text { Links to literature on social } \\
\text { capital [92,93] and social } \\
\text { network analysis [94]. }\end{array}$ & $\begin{array}{l}\text { Mostly single-resource } \\
\text { focus e.g., fisheries, } \\
\text { forests, irrigation } \\
\text { systems; at the local } \\
\text { resource user level. }\end{array}$ & $\begin{array}{l}\text { Local resource users, } \\
\text { can include some } \\
\text { involvement of } \\
\text { support stakeholders. }\end{array}$ & $\begin{array}{l}\text { Single resource focus, takes a } \\
\text { strongly institutional approach } \\
\text { to collaboration, does not } \\
\text { sufficiently account for } \\
\text { interdependencies among } \\
\text { multiple actors and resources. } \\
\text { See }[89,95,96] \text { for critiques. }\end{array}$ & {$[91,97,98]$} \\
\hline $\begin{array}{l}\text { 2. Community-Based Natural } \\
\text { Resource Management } \\
\text { (CBNRM) }[82,99,100] \text {. } \\
\text { Draws on CPRM theory [81]. }\end{array}$ & $\begin{array}{l}\text { Single or multiple } \\
\text { resource focus } \\
\text { (depending on context), } \\
\text { at the local community } \\
\text { level; devolution of } \\
\text { power to local } \\
\text { communities, often } \\
\text { focused on wildlife } \\
\text { management. }\end{array}$ & $\begin{array}{l}\text { Local resource users, } \\
\text { can include some } \\
\text { involvement of } \\
\text { support stakeholders } \\
\text { or researchers. Focus is } \\
\text { on decentralising } \\
\text { resource management. }\end{array}$ & $\begin{array}{l}\text { Primarily focused on } \\
\text { developing country context and } \\
\text { subsistence resource use; often } \\
\text { focused on participation rather } \\
\text { than collaboration; critiques of } \\
\text { efficacy or success e.g., see [95]. }\end{array}$ & {$[101,102]$} \\
\hline $\begin{array}{l}\text { 4. Various collaborative and } \\
\text { participatory approaches to } \\
\text { forest management } \\
\text { ('collaborative forest } \\
\text { approaches') [106,107]. Links } \\
\text { to CBNRM, ILA, CM } \\
\text { and ACM. }\end{array}$ & $\begin{array}{l}\text { Multiple resources, } \\
\text { implementation focused } \\
\text { at local level (some at } \\
\text { landscape level); mostly } \\
\text { in the tropics e.g., } \\
\text { participatory forest } \\
\text { management, } \\
\text { collaborative governance } \\
\text { of tropical landscapes. }\end{array}$ & $\begin{array}{l}\text { Local resource users } \\
\text { and community } \\
\text { representatives, } \\
\text { industry } \\
\text { representatives, } \\
\text { government officials, } \\
\text { researchers, etc. Often } \\
\text { driven by NGOs, } \\
\text { international } \\
\text { development } \\
\text { organisations. }\end{array}$ & $\begin{array}{l}\text { Appears not be a } \\
\text { well-developed, cohesive body } \\
\text { of academic literature on } \\
\text { collaboration specifically; many } \\
\text { of the lessons and case studies } \\
\text { published in grey literature, } \\
\text { using different terminology and } \\
\text { conceptual framings. }\end{array}$ & {$[87,108,109]$} \\
\hline $\begin{array}{l}\text { 6. Integrated Landscape } \\
\text { Approaches (ILA) [47,48,115]. } \\
\text { Some links to landscape } \\
\text { restoration and landscape } \\
\text { planning literature; draws on } \\
\text { its predecessor 'Integrated } \\
\text { Natural Resource } \\
\text { Management' (INRM) [116]. }\end{array}$ & $\begin{array}{l}\text { Multiple resources and } \\
\text { sectors, planning at } \\
\text { landscape level, action } \\
\text { locally focused; usually } \\
\text { emphasises multiple } \\
\text { ecosystem } \\
\text { services;cross-level } \\
\text { collaboration beyond the } \\
\text { local level. }\end{array}$ & $\begin{array}{l}\text { Emphasises } \\
\text { cross-sectoral } \\
\text { collaboration: resource } \\
\text { users, support } \\
\text { stakeholders, } \\
\text { government officials, } \\
\text { private partners and } \\
\text { investors, } \\
\text { researchers etc. }\end{array}$ & $\begin{array}{l}\text { Often focused on participation } \\
\text { rather than collaboration, } \\
\text { insufficient theoretical rigour } \\
\text { and development (strong policy } \\
\text { and practice focus) [88]. }\end{array}$ & {$[47,115,117]$} \\
\hline $\begin{array}{l}\text { 7. Collaboration in Complex, } \\
\text { Contested Contexts (CCCC) } \\
{[18,89,118] \text {. Links to literature }} \\
\text { on complexity thinking [119] } \\
\text { and critical institutionalism } \\
\text { [120]. }\end{array}$ & $\begin{array}{l}\text { Multiple resources, } \\
\text { multiple stakeholders, } \\
\text { cross-level focus; focuses } \\
\text { on interactions among } \\
\text { multiple actors and } \\
\text { resources, recognises } \\
\text { human agency and } \\
\text { interdependency } \\
\text { as pivotal. }\end{array}$ & $\begin{array}{l}\text { Multiple stakeholders } \\
\text { with contested } \\
\text { interests, local resource } \\
\text { users, support } \\
\text { stakeholders, } \\
\text { government; } \\
\text { recognition of } \\
\text { marginalised groups. }\end{array}$ & $\begin{array}{l}\text { A new, emerging field of } \\
\text { research, dispersed literature, } \\
\text { limited theoretical development } \\
\text { and empirical case studies. }\end{array}$ & {$[78,86,108,121,122]$.} \\
\hline
\end{tabular}




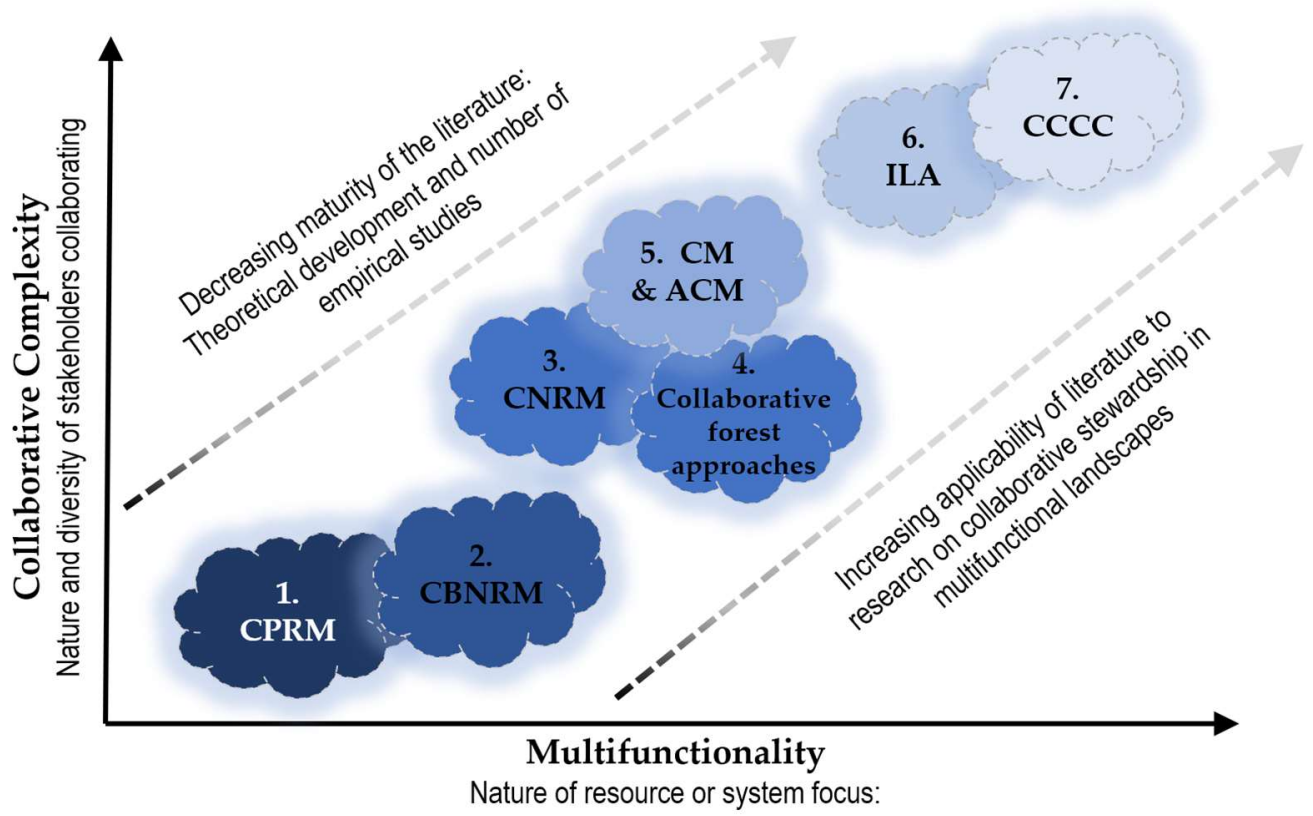

Note: The boundaries of each of the 'clouds' are intentionally 'fuzzy', as there is some overlap and they are not entirely discrete.

Figure 2. Bodies of literature on collaboration in natural resource management of relevance to studying collaboration in multifunctional landscapes (Refer to Table 2 for description of acronyms).

\section{Critique of Existing Literature on Collaboration and Social-Ecological Systems}

Recognition of natural resource management as a complex endeavour involving multiple, diverse stakeholders is not new. For example, as long ago as 1993, Grimble and Quan (1993, cited in Grimble and Wellard [123] (p. 177)) stated that many natural resource management situations are "characterised by a complex web of interests and tradeoffs between interacting sets of local people, government departments, national and international planners, and professional advisers". However, we argue that existing literature on collaboration has not sufficiently accounted for these complexities, and they may be constraining realisation of stewardship ideals in practice. One reason for the lack of attention to such social complexities may relate to an over-emphasis on organised institutional, governance, and rule-based approaches (for examples of this critique see Campbell et al. [95] and Cleaver [120]) and a subsequent tendency to underplay the nuances of social systems including human agency, social-relational, and political processes [89,124-127].

Existing literature on collaboration and the social aspects of social-ecological systems has been critiqued in three main arenas:

1. agency of individual human actors;

2. social-relational dynamics among actors as they interact with one another and come together in collectives; and

3. situatedness of human interactions in the social-ecological context.

I discuss each of these in turn below.

Firstly, critiques relating to individual human actors concern the lack of attention paid to human agency and interactions with broader structures $[124,128]$ and to the role of individual values, ethics and morals as mediating factors $[129,130]$. This is particularly relevant considering the moral-ethical basis of stewardship described above [9] (See Section 2.1). In order to better understand collaboration for stewardship in multifunctional landscapes, it is necessary to investigate the interplay between individual stewards' values, morals and ethics and those of other stakeholders in the landscape. 
Secondly, critiques relating to the social-relational dynamics among actors in collaborative processes foreground social diversity and complexity as a key challenge [125]. Stakeholders come into collaborative processes with a diversity of knowledge types and perspectives and actors may be temporally, spatially, and institutionally fragmented [89]. Cross-level interplay and multi-scale feedback mechanisms between diverse actors and between social actors and ecosystems makes collaboration even more challenging $[89,131]$. Another important issue is unequal power relations among actors and the influence of political processes [125,131], which can lead to contestation and make it difficult to achieve the ideals of equity [132].

Thirdly, critiques relating to the situatedness of human interactions within the social-ecological context relate to challenges of organisational and institutional complexity $[121,131]$, and a lack of understanding about the influence of place and place identity on people's relationships to nature and to other stakeholders [133]. The SES framework proposed by Ostrom [134] has been criticised for insufficiently capturing the interdependencies in complex, contested contexts where multiple stakeholders interact with multiple resources through multiple activities, which affect multiple resource units and systems (as in landscapes), i.e., the framework also does not sufficiently represent the dynamic and interactive aspects of resources and actor activities $[18,89,96]$. Moreover, a number of authors point towards a paucity of situated analyses which takes into account local dynamics and social-ecological contexts on natural resource management [126,127]. For example, Cote \& Nightingale [127] argue that social-ecological systems research should seek to understand the cultural values, historical context and ethical standpoints of actors, and that our understanding of the role of local actors in natural resource management should be drawn out of a situated understanding of place and context: "we advocate to situate our inquiries ... based on the recognition that power operates in and through socio-environmental systems in ways that link together the social and environmental at conceptual as well as empirical levels." [127] (p. 481). Furthermore, the basis of much of the literature on CPRM, which is an antecedent of many of the more recent literatures on collaboration (Table 2), is institutional economics and rational game theory. Critics argue that a focus on the design of institutions for natural resource management has limited explanatory power to understand human interactions with natural resources because the application of rules varies across contexts and is so strongly mediated by agency, social-relational processes such as power relations and contestation, and the culture and history of place $[124,126,127]$.

Despite these concerns, the more established bodies of literature, such as CPRM, CBNRM, and CNRM do offer a wealth of theories, well-developed concepts, and a large body of empirical studies which provide important insights on collaboration for stewardship in landscapes. The more recent literature on CM and ACM is particularly relevant here, as it is framed by the concepts of social-ecological systems and resilience. The focus of this literature is, however, often on single resources and much of the literature is from the Global North and therefore application to contexts of multifunctionality in the Global South, where resource contestation and concerns about equitable benefits are a growing concern, may be limited. Much of the literature on ILAs implies that collaboration across an entire landscape can be facilitated through a single platform. Similarly, collaboration often comes across as a panacea which, if it can be achieved, could solve all the sustainability challenges inherent in complex, multifunctional landscapes. There are nevertheless important lessons for complex collaborative settings in this literature.

Since questions on collaboration in ILA and CCCC literature are still in the early stages of theoretical and conceptual development $[86,88,89]$, there is a need for further research on collaboration for stewardship in complex contexts characterised by 'many multiples' $[18,89]$. The literature on ILA and CCCC illuminates some important research opportunities in this regard. Effective implementation of ILAs, and similarly of co-management and adaptive co-management approaches, is dependent on effective institutional and governance arrangements, which are in turn mediated by the quality of relationships between diverse stakeholders. These arrangements need to operate at and/or above the landscape level and are recognised as possibly the biggest constraint in bringing about sustainable 
management of landscapes $[47,135]$. Hence, there is a need for research on social-relational processes involved in implementing a landscape approach through collaborative institutional mechanisms [115].

Thus, it is necessary to pay attention to the role of human agency, social diversity, and intersubjectivity among actors involved in collaboration. This requires contextual, situated, qualitative research approaches, and requires paying attention to interactions among factors that influence collaboration $[89,125,128]$. Below we propose the pathways approach as a theoretical 'waymark' to strengthen research on collaboration, arguing that this approach holds the potential to assist researchers in addressing many of the shortcomings discussed above.

\section{The Pathways Approach: A Theoretical Waymark to Deepen Research on Collaboration for Stewardship in Landscapes}

Research on collaboration for stewardship in landscapes (i.e., complex, contested contexts) requires deepening on aspects relating to individual human actors, social-relational dynamics among actors, and the situatedness of human interactions within the social-ecological context. We now propose a waymark to guide and deepen such research efforts. A waymark is defined as "a sign forming one of a series used to mark out a route" [136], and we use it here as a metaphor for a body of theory (the pathways approach) which can form part of a series of theories to mark out a route towards a new perspective for research on collaboration for stewardship. We intentionally suggest a waymark, as we consider this an evolving area of research to which we hope to contribute a sign along the way (rather than an inflexible framework or agenda). We do this in recognition that conducting situated [127], contextual [137], and place-based research [15] requires flexible research approaches. Theoretical, methodological, and philosophical approaches which are open to unexpected surprises and changes in direction and allow space for action-oriented knowledge co-production with local stakeholders, are necessary [138]. We argue that research on collaboration can be deepened by drawing on the pathways approach as a theoretical waymark.

We agree with Karpouzoglou [139] that theoretical multiplicity (combination of theories to address complex problems) is needed to advance sustainability research and that it can help to address some of the 'epistemologically grey areas' such as human agency, social diversity, and power inequalities pointed out above. With this in mind, the pathways approach offers promising theory to deepen research on collaboration in social-ecological systems research. To this end, Leach et al. [41] (p. 84) offer a conceptual model for sustainability based on the notion of navigating pathways between the ecological ceiling and the social foundation, i.e., in the 'safe and just operating space for humanity', based on the doughnut model described above (See Section 2.2) [42]. This approach is integrated with an agenda called the 'Three Ds' to support researchers, practitioners, and policy-makers in identifying equitable and sustainable pathways for development. The 'Three Ds' are: Direction (purposefully steering pathways toward transformation needed to stay within a safe operating space), Diversity (nurturing more diverse approaches and forms of innovation, fostering diversity within social-ecological systems), and Distribution (sharing the 'the safe operating space' equitably between different people, and asking about who gains and who loses) [23,41]. This approach can guide efforts to develop pathways towards managing trade-offs between the multiple benefits and their diverse beneficiaries, provided by a variety of ecosystem services in landscapes $[52,53]$.

The pathways approach can contribute to deepening research and practice on stewardship and collaboration, and we illustrate some such opportunities here by briefly discussing the implications of the Three Ds for collaboration. The first D- 'Direction' is about the goals towards which an initiative is moving, and this should be primarily concerned with keeping pathways within the safe and just operating space. Social-ecological systems and resilience approaches (Section 2.2) and most of the existing collaboration literature (Table 1) generally work towards the normative goal of resilience and sustainability for a system as a whole [140]. However, these goals are invariably context-specific and are likely to be contested [137], and landscape stewardship approaches are inherently normative [44]. Therefore, the task of collaborative initiatives is to deliberately negotiate objectives or goals, recognising 
that there may be more than one way of defining the problem at hand and more than one pathway to sustainability. The pathways approach suggests that multiple alternatives or pathways to sustainability within the safe and just space are necessary, though all should seek to remain within both the planetary and the social boundaries.

This brings us to the second D-'Diversity'. Both the SES and resilience approach and the pathways approach recognise the importance of diversity for resilience and sustainability [140]. Recent literature on stewardship points to the diversity of values and ideologies which the concept carries for different actors and stakeholders, in different contexts $[12,27,67]$. Yet, existing literature on collaboration (Table 2) often emphasises consensus-building as a key process of collaboration [85], implying a reduction or 'flattening' of diversity as an outcome of collaborative deliberations. In multifunctional landscapes, with diverse stakeholders, a more pluralistic approach may be better suited $[67,87]$. More than one pathway to sustainability and encouraging the practice of more than one stewardship ideology [12], may mean more than one collaboration in the landscape. This may mean building 'collaborations' (plural), rather than 'collaboration' (singular). Furthermore, the pathways approach calls for adaptive, context-specific approaches to addressing sustainability challenges, working towards a basket of options-or multiple collaborative pathways-rather than singular solutions [137].

The third D-'Distribution', has particularly far-reaching implications for collaboration. The notion of distribution speaks to the concerns of equity, inclusion, power imbalances, and politics which are under-researched in social-ecological systems [128,131], and also require further attention in stewardship policies, practice and research [12]. Existing literature often emphasises 'common entry points' [47] or 'shared problems' [77,79]; however, in many landscapes, resources are contested and collaboration around a shared interest may not be possible $[89,107]$. If we recognise the contested nature of landscapes and the need for trade-offs [75], then the challenge of distributing the benefits of multiple ecosystem services means that conflict is more likely than collaboration.

Sharing of the 'safe and just space for humanity' is a lofty global goal, but how can the benefits of ecosystem services be shared at the local level? Recognising the need to pay attention to multiple, diverse framings and narratives about sustainability challenges in a landscape [137], we have to pause and ask: stewardship for whom? Leach et al. [137] (p. 2) argue that "we need to recognise the essentially plural and political nature of our quest for pathways to sustainability". By the same token, we need to appreciate the essentially plural and political nature of our quest for collaboration towards stewardship of multifunctional landscapes.

\section{Conclusions}

The world faces pressing social-ecological challenges, locally and globally, and stewardship has a role to play in addressing these. However, the question of how to achieve social-ecological stewardship in practice remains, and robust place-based research is required to support improved practice. We have proposed landscapes as suitable place-based arenas for investigating how stewardship is achieved in practice. Since all landscapes are multifunctional and are complex and contested contexts, bringing about stewardship in practice requires collaboration among multiple stakeholders. We have synthesised literature on stewardship, multifunctional landscapes, and collaboration offering a new combination of perspectives to guide research in this area. This has revealed that literature on collaboration needs further attention and development in order to account for the complex, contested contexts in which stewardship plays out. To deepen understanding of stewardship practice and collaboration in these contexts, further research is needed to investigate the agency of individual human actors, the complex social-relational dynamics among actors, and the situatedness of actors within place-based social-ecological systems. The pathways approach offers a promising theoretical waymark to further develop this research. 
Author Contributions: All four authors jointly conceptualized the study. Jessica Cockburn wrote the paper, with significant conceptual and editorial input from Georgina Cundill, Sheona Shackleton and Mathieu Rouget. All authors read and approved the submitted version of the manuscript.

Funding: This research was funded by the following funders: J.C. acknowledges a NRF-DST Innovation Doctoral Research Scholarship, G.C. acknowledges National Research Foundation support through grants 93446 and 90694. M.R. acknowledges the South African Research Chairs Initiative of the Department of Science and Technology and the NRF. Opinions expressed, and conclusions arrived at, are those of the author and are not necessarily to be attributed to the NRF. We also acknowledge Rhodes University for the Henderson Scholarship and for Research funds for Sheona Shackleton.

Acknowledgments: We would like to thank two anonymous reviewers for their useful comments which helped to improve the quality of the arguments made in the paper.

Conflicts of Interest: The authors declare no conflict of interest. The funding sponsors had no role in the design of the study; in the collection, analyses, or interpretation of data; in the writing of the manuscript, and in the decision to publish the results.

\section{References}

1. Chapin, F.S., III; Carpenter, S.R.; Kofinas, G.P.; Folke, C.; Abel, N.; Clark, W.C.; Olsson, P.; Smith, D.M.S.; Walker, B.; Young, O.R.; et al. Ecosystem stewardship: Sustainability strategies for a rapidly changing planet. Trends Ecol. Evol. 2009, 25, 241-249. [CrossRef] [PubMed]

2. Folke, C.; Biggs, R.; Norström, A.V.; Reyers, B.; Rockström, J. Social-ecological resilience and biosphere-based sustainability science. Ecol. Soc. 2016, 21, 41. [CrossRef]

3. Chapin, F.S.; Chapin, C.; Kofinas, G.P.; Folke, C. Principles of Ecosystem Stewardship: Resilience-Based Natural Resource Management in a Changing World; Springer: New York, NY, USA, 2009.

4. Chapin, F.S.; Power, M.E.; Pickett, S.T.A.; Freitag, A.; Reynolds, J.A.; Jackson, R.B.; Lodge, D.M.; Duke, C.; Collins, S.L.; Power, A.G.; et al. Earth stewardship: Science for action to sustain the human-earth system. Ecosphere 2011, 2, 1-20. [CrossRef]

5. Steffen, W.; Persson, Å.; Deutsch, L.; Zalasiewicz, J.; Williams, M.; Richardson, K.; Crumley, C.; Crutzen, P.; Folke, C.; Gordon, L.; et al. The Anthropocene: From global change to planetary stewardship. AMBIO 2011, 40, 739-761. [CrossRef] [PubMed]

6. Raworth, K. A safe and just space for humanity: Can we live within the doughnut. Oxfam Policy Pract. Clim. Chang. Resil. 2012, 8, 1-26.

7. ISSC IDS; UNESCO. World Social Science Report 2016, Challenging Inequalities: Pathways to a Just World; UNESCO Publishing: Paris, France, 2016.

8. Millennium Assessment. Millenium Ecosystem Assessment: Ecosystems and Human Well-Being: Current State and Trends; Island Press: Washington, DC, USA, 2005; Volume 1.

9. Welchman, J. A defence of environmental stewardship. Environ. Values 2012, 21, 297-316. [CrossRef]

10. Berry, R.J. Environmental Stewardship: Critical Perspectives, Past and Present; T\&T Clark: London, UK, 2006.

11. Worrell, R.; Appleby, M. Stewardship of natural resources: Definition, ethical and practical aspects. J. Agric. Environ. Ethics 2000, 12, 263-277. [CrossRef]

12. Mathevet, R.; Bousquet, F.; Raymond, C.M. The concept of stewardship in sustainability science and conservation biology. Biol. Conserv. 2018, 217, 363-370. [CrossRef]

13. Bennett, N.J.; Whitty, T.S.; Finkbeiner, E.; Pittman, J.; Bassett, H.; Gelcich, S.; Allison, E.H. Environmental stewardship: A conceptual review and analytical framework. Environ. Manag. 2018, 61, 597-614. [CrossRef] [PubMed]

14. Barendse, J.; Roux, D.; Currie, B.; Wilson, N.; Fabricius, C. A broader view of stewardship to achieve conservation and sustainability goals in South Africa. S. Afr. J. Sci. 2016, 112, 1-15. [CrossRef]

15. Carpenter, S.R.; Folke, C.; Norström, A.; Olsson, O.; Schultz, L.; Agarwal, B.; Balvanera, P.; Campbell, B.; Castilla, J.C.; Cramer, W.; et al. Program on Ecosystem Change and Society: An international research strategy for integrated social-ecological systems. Curr. Opin. Environ. Sustain. 2012, 4, 134-138. [CrossRef]

16. Angelstam, P.; Grodzynskyi, M.; Andersson, K.; Axelsson, R.; Elbakidze, M.; Khoroshev, A.; Kruhlov, I.; Naumov, V. Measurement, collaborative learning and research for sustainable use of ecosystem services: Landscape concepts and europe as laboratory. AMBIO 2013, 42, 129-145. [CrossRef] [PubMed] 
17. Bieling, C.; Plieninger, T. The Science and Practice of Landscape Stewardship; Cambridge University Press: Cambridge, UK, 2017.

18. Poteete, A.R. Levels, scales, linkages, and other 'multiples' affecting natural resources. Int. J. Commons 2012, 6, 134-150. [CrossRef]

19. Lescourret, F.; Magda, D.; Richard, G.; Adam-Blondon, A.-F.; Bardy, M.; Baudry, J.; Doussan, I.; Dumont, B.; Lefèvre, F.; Litrico, I.; et al. A social-ecological approach to managing multiple agro-ecosystem services. Curr. Opin. Environ. Sustain. 2015, 14, 68-75. [CrossRef]

20. Angelstam, P.; Elbakidze, M.; Axelsson, R.; Dixelius, M.; Törnblom, J. Knowledge production and learning for sustainable landscapes: Seven steps using social-ecological systems as laboratories. Ambio 2013, 42, 116-128. [CrossRef] [PubMed]

21. O'Farrell, P.J.; Anderson, P.M.L. Sustainable multifunctional landscapes: A review to implementation. Curr. Opin. Environ. Sustain. 2010, 2, 59-65. [CrossRef]

22. Minang, P.A.; van Noordwijk, M.; Freeman, O.E.; Duguma, L.A.; Mbow, C.; de Leeuw, J.; Catacutan, D. Introduction and basic propositions. In Climate-Smart Landscapes: Multifunctionality in Practice; Minang, P.A., van Noordwijk, M., Freeman, O.E., Mbow, C., de Leeuw, J., Catacutan, D., Eds.; World Agroforestry Centre (ICRAF): Nairobi, Kenya, 2014; pp. 3-17.

23. Leach, M.; Rockström, J.; Raskin, P.; Scoones, I.; Stirling, A.C.; Smith, A.; Thompson, J.; Millstone, E.; Ely, A.; Arond, E.; et al. Transforming innovation for sustainability. Ecol. Soc. 2012, 17, 11. [CrossRef]

24. Raymond, C.M.; Singh, G.G.; Benessaiah, K.; Bernhardt, J.R.; Levine, J.; Nelson, H.; Turner, N.J.; Norton, B.; Tam, J.; Chan, K.M.A. Ecosystem services and beyond: Using multiple metaphors to understand human-environment relationships. BioScience 2013, 63, 536-546. [CrossRef]

25. Ridings, P. Redefining environmental stewardship to deliver governance frameworks for marine biodiversity beyond national jurisdiction. ICES J. Mar. Sci. 2018, 75, 435-443. [CrossRef]

26. Berkes, F.; Doubleday, N.; Cumming, G. Aldo Leopold's land health from a resilience point of view: Self-renewal capacity of social-ecological systems. EcoHealth 2012, 9, 278-287. [CrossRef] [PubMed]

27. Raymond, C.M.; Bieling, C.; Fagerholm, N.; Martin-Lopez, B.; Plieninger, T. The farmer as a landscape steward: Comparing local understandings of landscape stewardship, landscape values, and land management actions. AMBIO 2016, 45, 173-184. [CrossRef] [PubMed]

28. Peterson, M.N.; Peterson, T.R.; Lopez, A.; Liu, J. Views of private-land stewardship among Latinos on the Texas-Tamaulipas border. Environ. Commun. J. Nat. Cult. 2010, 4, 406-421. [CrossRef]

29. Attfield, R. Stewardship. In Encyclopedia of Global Bioethics; ten Have, H., Ed.; Springer International Publishing: Dordrecht, The Netherlands, 2014; pp. 1-11.

30. McArthur, M. The Meaning and Practice of Stewardship. Master's Thesis, Faculty of Environmental Design, University of Calgary, Calgary, AB, Canada, 2012.

31. Welchman, J. Environmental versus natural heritage stewardship: Nova Scotia's Annapolis River and the Canadian Heritage River System. In Restoring Layered Landscapes: History, Ecology, and Culture; Hourdequin, M., Havlick, D.G., Eds.; Oxford University Press: New York, NY, USA, 2015; pp. 112-132.

32. Chapin, F.S.; Knapp, C.N. Sense of place: A process for identifying and negotiating potentially contested visions of sustainability. Environ. Sci. Policy 2015, 53, 38-46. [CrossRef]

33. Chapin, F.S.; Kofinas, G.P.; Folke, C.; Carpenter, S.R.; Olsson, P.; Abel, N.; Biggs, R.; Naylor, R.L.; Pinkerton, E.; Stafford, D.M.; et al. Resilience-based stewardship: Strategies for navigating sustainable pathways in a changing world. In Principles of Ecosystem Stewardship: Resilience-Based Natural Resource Management in a Changing World; Chapin, F.S., Kofinas, G.P., Folke, C., Eds.; Springer: New York, NY, USA, 2009; pp. 319-337.

34. Carr, A. Grass Roots and Green Tape: Principles and Practices of Environmental Stewardship; Federation Press: Leichhardt, Australia, 2002.

35. Binder, C.R.; Hinkel, J.; Bots, P.W.G.; Pahl-Wostl, C. Comparison of frameworks for analyzing social-ecological systems. Ecol. Soc. 2013, 18, 26. [CrossRef]

36. Holling, C.S. Resilience and stability of ecological systems. Ann. Rev. Ecol. Syst. 1973, 4, 1-23. [CrossRef]

37. Berkes, F.; Folke, C. Linking Social and Ecological Systems: Management Practices and Social Mechanisms for Building Resilience; Cambridge University Press: Cambridge, UK, 1998.

38. Folke, C. Resilience: The emergence of a perspective for social-ecological systems analyses. Glob. Environ. Chang. 2006, 16, 253-267. [CrossRef] 
39. Walker, B.; Holling, C.S.; Carpenter, S.R.; Kinzig, A.P. Resilience, adaptability and transformability in social-ecological systems. Ecol. Soc. 2004, 9, 5. [CrossRef]

40. Chapin, F.S., III; Pickett, S.A.; Power, M.; Jackson, R.; Carter, D.; Duke, C. Earth stewardship: A strategy for social-ecological transformation to reverse planetary degradation. J. Environ. Stud. Sci. 2011, 1, 44-53. [CrossRef]

41. Leach, M.; Raworth, K.; Rockström, J. Between social and planetary boundaries: Navigating pathways in the safe and just space for humanity. In World Social Science Report 2013, Changing Global Environments; ISSC, UNESCO, Eds.; OECD Publishing: Paris, France; UNESCO Publishing: Paris, France, 2013.

42. Raworth, K. Doughnut Economics: Seven Ways to Think Like a 21st-Century Economist; Random House Business Books: London, UK, 2017.

43. Rockstrom, J.; Steffen, W.; Noone, K.; Persson, A.; Chapin, F.S.; Lambin, E.F.; Lenton, T.M.; Scheffer, M.; Folke, C.; Schellnhuber, H.J.; et al. A safe operating space for humanity. Nature 2009, 461, 472-475. [CrossRef] [PubMed]

44. Plieninger, T.; Bieling, C. The emergence of landscape stewardship in practice, policy and research. In The Science and Practice of Landscape Stewardship; Bieling, C., Plieninger, T., Eds.; Cambridge University Press: Cambridge, UK, 2017; pp. 1-18.

45. Fischer, J.; Meacham, M.; Queiroz, C. A plea for multifunctional landscapes. Front. Ecol. Environ. 2017, 15, 59. [CrossRef]

46. Arts, B.; Buizer, M.; Horlings, L.; Ingram, V.; van Oosten, C.; Opdam, P. Landscape approaches: A state-of-the-art review. Ann. Rev. Environ. Resour. 2017, 42, 439-463. [CrossRef]

47. Sayer, J.; Sunderland, T.; Ghazoul, J.; Pfund, J.-L.; Sheil, D.; Meijaard, E.; Venter, M.; Boedhihartono, A.K.; Day, M.; Garcia, C.; et al. Ten principles for a landscape approach to reconciling agriculture, conservation, and other competing land uses. Proc. Natl. Acad. Sci. USA 2013, 110, 8349-8356. [CrossRef] [PubMed]

48. Minang, P.A.; van Noordwijk, M.; Freeman, O.E.; Mbow, C.; de Leeuw, J.; Catacutan, D. Climate-Smart Landscapes: Multifunctionality in Practice; World Agroforestry Centre (ICRAF): Nairobi, Kenya, 2014.

49. Robinson, L.W.; Ontiri, E.; Alemu, T.; Moiko, S.S. Transcending landscapes: Working across scales and levels in pastoralist rangeland governance. Environ. Manag. 2017, 60, 185-199. [CrossRef] [PubMed]

50. Prager, K.; Reed, M.; Scott, A. Encouraging collaboration for the provision of ecosystem services at a landscape scale-Rethinking agri-environmental payments. Land Use Policy 2012, 29, 244-249. [CrossRef]

51. De Groot, R.S.; Wilson, M.A.; Boumans, R.M.J. A typology for the classification, description and valuation of ecosystem functions, goods and services. Ecol. Econ. 2002, 41, 393-408. [CrossRef]

52. Raudsepp-Hearne, C.; Peterson, G.D.; Bennett, E.M. Ecosystem service bundles for analyzing tradeoffs in diverse landscapes. Proc. Natl. Acad. Sci. USA 2010, 107, 5242-5247. [CrossRef] [PubMed]

53. Scherr, S.J.; McNeely, J.A. Biodiversity conservation and agricultural sustainability: Towards a new paradigm of 'ecoagriculture' landscapes. Philos. Trans. Biol. Sci. 2008, 363, 477-494. [CrossRef] [PubMed]

54. Penker, M.; Enengel, B.; Mann, C.; Aznar, O. Understanding landscape stewardship—Lessons to be learned from public service economics. J. Agric. Econ. 2013, 64, 54-72. [CrossRef]

55. Gordon, L.J.; Finlayson, C.M.; Falkenmark, M. Managing water in agriculture for food production and other ecosystem services. Agric. Water Manag. 2010, 97, 512-519. [CrossRef]

56. Zhang, W.; Ricketts, T.H.; Kremen, C.; Carney, K.; Swinton, S.M. Ecosystem services and dis-services to agriculture. Ecol. Econ. 2007, 64, 253-260. [CrossRef]

57. Power, A.G. Ecosystem services and agriculture: Tradeoffs and synergies. Philos. Trans. Biol. Sci. 2010, 365, 2959-2971. [CrossRef] [PubMed]

58. Clay, J. World Agriculture and the Environment: A Commodity-by-Commodity Guide to Impacts and Practices; Island Press: Washington, DC, USA, 2004.

59. Tscharntke, T.; Clough, Y.; Wanger, T.C.; Jackson, L.; Motzke, I.; Perfecto, I.; Vandermeer, J.; Whitbread, A. Global food security, biodiversity conservation and the future of agricultural intensification. Biol. Conserv. 2012, 151, 53-59. [CrossRef]

60. Penker, M. Organising adaptive and collaborative landscape stewardship on farmland. In The Science and Practice of Landscape Stewardship; Bieling, C., Plieninger, T., Eds.; Cambridge University Press: Cambridge, UK, 2017; pp. 103-120.

61. Bieling, C.; Plieninger, T. Leveraging landscape stewardship. In The Science and Practice of Landscape Stewardship; Bieling, C., Plieninger, T., Eds.; Cambridge University Press: Cambridge, UK, 2017; pp. 370-382. 
62. Foley, J.A.; DeFries, R.; Asner, G.P.; Barford, C.; Gordon, B.; Carpenter, S.R.; Chapin, F.S.; Coe, M.T.; Daily, G.C.; Gibbs, H.K.; et al. Global consequences of land use. Science 2005, 309, 570-574. [CrossRef] [PubMed]

63. Fischer, J.; Lindenmayer, D.B.; Manning, A.D. Biodiversity, ecosystem function, and resilience: Ten guiding principles for commodity production landscapes. Front. Ecol. Environ. 2006, 4, 80-86. [CrossRef]

64. IPCC. Climate Change 2014: Synthesis Report. Contribution of Working Groups I, II and III to the Fifth Assessment Report of the Intergovernmental Panel on Climate Change; Core Writing Team, Pachauri, R.K., Meyer, L.A., Eds.; Intergovernmental Panel on Climate Change: Geneva, Switzerland, 2014.

65. Thrupp, L.A. Linking agricultural biodiversity and food security: The valuable role of agrobiodiversity for sustainable agriculture. Int. Aff. 2000, 76, 283-297. [CrossRef]

66. Opdam, P. How landscape stewardship emerges out of landscape planning. In The Science and Practice of Landscape Stewardship; Bieling, C., Plieninger, T., Eds.; Cambridge University Press: Cambridge, UK, 2017; pp. 331-346.

67. Conrad, E. Human and social dimensions of landscape stewardship. In The Science and Practice of Landscape Stewardship; Bieling, C., Plieninger, T., Eds.; Cambridge University Press: Cambridge, UK, 2017; pp. 38-53.

68. Chapin, F.S. Ecological foundations of landscape stewardship. In The Science and Practice of Landscape Stewardship; Bieling, C., Plieninger, T., Eds.; Cambridge University Press: Cambridge, UK, 2017; pp. 21-34.

69. Tscharntke, T.; Klein, A.M.; Kruess, A.; Steffan-Dewenter, I.; Thies, C. Landscape perspectives on agricultural intensification and biodiversity-ecosystem service management. Ecol. Lett. 2005, 8, 857-874. [CrossRef]

70. Flitcroft, R.L.; Cerveny, L.K.; Bormann, B.T.; Smith, J.E.; Asah, S.T.; Fischer, A.P. The emergence of watershed and forest collaborative. In People, Forests, and Change: Lessons from the Pacific Northwest; Olson, D.H., Van Horne, B., Eds.; Island Press: Washington, DC, USA, 2017; pp. 116-130.

71. Goldman, R.L.; Thompson, B.H.; Daily, G.C. Institutional incentives for managing the landscape: Inducing cooperation for the production of ecosystem services. Ecol. Econ. 2007, 64, 333-343. [CrossRef]

72. Stallman, H.R. Ecosystem services in agriculture: Determining suitability for provision by collective management. Ecol. Econ. 2011, 71, 131-139. [CrossRef]

73. Gibson, C.C.; Ostrom, E.; Ahn, T.K. The concept of scale and the human dimensions of global change: A survey. Ecol. Econ. 2000, 32, 217-239. [CrossRef]

74. Frost, P.; Campbell, B.; Medina, G.; Usongo, L. Landscape-scale approaches for integrated natural resource management in tropical forest landscapes. Ecol. Soc. 2006, 11, 30. [CrossRef]

75. Rodríguez, J.P.; Beard, J.T.D.; Bennett, E.M.; Cumming, G.S.; Cork, S.J.; Agard, J.; Dobson, A.P.; Peterson, G.D. Trade-offs across space, time, and ecosystem services. Ecol. Soc. 2006, 11, 28. [CrossRef]

76. Buck, L.E.; Scherr, S.J.; Planicka, C.M.; Heiner, K. Building partnerships for landscape stewardship. In The Science and Practice of Landscape Stewardship; Bieling, C., Plieninger, T., Eds.; Cambridge University Press: Cambridge, UK, 2017; pp. 57-77.

77. Gray, B. Conditions facilitating interorganizational collaboration. Hum. Relat. 1985, 38, 911-936. [CrossRef]

78. Margerum, R.D.; Robinson, C.J. The Challenges of Collaboration in Environmental Governance: Barriers and Responses; Edward Elgar Publishing Ltd.: Cheltenham, UK, 2016.

79. Wondolleck, J.M.; Yaffee, S.L. Making Collaboration Work: Lessons from Innovation in Natural Resource Management; Island Press: Washington, DC, USA, 2000.

80. Armitage, D.; Berkes, F.; Doubleday, N. Adaptive Co-Management: Collaboration, Learning, and Multi-Level Governance; UBC Press: Vancouver, BC, Canada, 2007.

81. Ostrom, E. Governing the Commons. The Evolution of Institutions for Collective Action; Cambridge University Press: New York, NY, USA, 1990.

82. Fabricius, C.; Koch, E. Rights, Resources and Rural Development: Community-Based Natural Resource Management in Southern Africa; Earthscan: London, UK, 2004.

83. Koontz, T.M.; Thomas, C.W. What do we know and need to know about the environmental outcomes of collaborative management? Public Adm. Rev. 2006, 66, 111-121. [CrossRef]

84. Margerum, R.D. A typology of collaboration efforts in environmental management. Environ. Manag. 2008, 41, 487-500. [CrossRef] [PubMed]

85. Margerum, R.D.; Robinson, C.J. Introduction: The challenges of collaboration in environmental governance. In The Challenges of Collaboration in Environmental Governance: Barriers and Responses; Margerum, R.D., Robinson, C.J., Eds.; Edward Elgar Publishing Ltd.: Cheltenham, UK, 2016; pp. 1-24. 
86. Kerr, J. Watershed management: Lessons from common property theory. Int. J. Commons 2007, 1, 89-110. [CrossRef]

87. Wollenberg, E.; López, C.; Anderson, J. Though All Things Differ: Pluralism as a Basis for Cooperation in Forests; CIFOR: Bogor, Indonesia, 2005.

88. Erbaugh, J.; Agrawal, A. Clarifying the landscape approach: A letter to the editor on "integrated landscape approaches to managing social and environmental issues in the tropics". Glob. Chang. Biol. 2017, 23, 4453-4454. [CrossRef] [PubMed]

89. Patterson, J. Purposeful collective action in ambiguous and contested situations: Exploring 'enabling capacities' and cross-level interplay. Int. J. Commons 2017, 11, 248-274. [CrossRef]

90. Reed, J.; van Vianen, J.; Barlow, J.; Sunderland, T. Have integrated landscape approaches reconciled societal and environmental issues in the tropics? Land Use Policy 2017, 63, 481-492. [CrossRef]

91. Ostrom, E.; Cox, M. Moving beyond panaceas: A multi-tiered diagnostic approach for social-ecological analysis. Environ. Conserv. 2010, 37, 451-463. [CrossRef]

92. Ostrom, E.; Ahn, T.K. Foundations of Social Capital; Edward Elgar Publishing Ltd.: Cheltenham, UK, 2003.

93. Pretty, J.; Smith, D. Social capital in biodiversity conservation and management. Conserv. Biol. 2004, 18, 631-638. [CrossRef]

94. Bodin, Ö.; Crona, B.I. The role of social networks in natural resource governance: What relational patterns make a difference? Glob. Environ. Chang. 2009, 19, 366-374. [CrossRef]

95. Campbell, B.; Mandondo, A.; Nemarundwe, N.; Sithole, B.; De JonG, W.; Luckert, M.; Matose, F. Challenges to proponents of common property recource systems: Despairing voices from the social forests of Zimbabwe. World Dev. 2001, 29, 589-600. [CrossRef]

96. Hinkel, J.; Cox, M.E.; Schlüter, M.; Binder, C.R.; Falk, T. A diagnostic procedure for applying the social-ecological systems framework in diverse cases. Ecol. Soc. 2015, 20, 32. [CrossRef]

97. McGinnis, M.D.; Ostrom, E. Social-ecological system framework: Initial changes and continuing challenges. Ecol. Soc. 2014, 19, 30. [CrossRef]

98. Ostrom, E. Understanding Institutional Diversity; Princeton University Press: Princeton, NJ, USA, 2005.

99. Taylor, R. Community-based natural resource management in Zimbabwe: The experience of campfire. Biodivers. Conserv. 2009, 18, 2563-2583. [CrossRef]

100. Child, B.; Barnes, G. The conceptual evolution and practice of community-based natural resource management in Southern Africa: Past, present and future. Environ. Conserv. 2010, 37, 283-295. [CrossRef]

101. Campbell, B.M.; Shackleton, S. The organizational structures for community-based natural resources management in Southern Africa. Afr. Stud. Q. 2001, 5, 87-114.

102. Turner, S. Community-based natural resource management and rural livelihoods. In Rights, Resources and Rural Development: Community-Based Natural Resource Management in Southern Africa; Fabricius, C., Koch, E., Eds.; Earthscan: London, UK, 2004; pp. 44-65.

103. Ansell, C.; Gash, A. Collaborative governance in theory and practice. J. Public Adm. Res. Theory 2007, 18, 543-571. [CrossRef]

104. Cheng, A.S.; Mattor, K.M. Why won't they come? Stakeholder perspectives on collaborative national forest planning by participation level. Environ. Manag. 2006, 38, 545-561. [CrossRef] [PubMed]

105. Lubell, M. Collaborative watershed management: A view from the grassroots. Policy Stud. J. 2004, 32, 341-361. [CrossRef]

106. Blomley, T.; Pfliegner, K.; Isango, J.; Zahabu, E.; Ahrends, A.; Burgess, N. Seeing the wood for the trees: An assessment of the impact of participatory forest management on forest condition in Tanzania. Oryx 2008, 42, 380-391. [CrossRef]

107. Colfer, C.J.P. The Complex Forest: Communities, Uncertainty, and Adaptive Collaborative Management; RFF Press-Resources for the Future: Washington, DC, USA, 2005.

108. Colfer, C.J.P.; Pfund, J.L. Collaborative Governance of Tropical Landscapes; Earthscan: London, UK, 2012.

109. Buck, L.E.; Sherr, S.J. Building innovation systems for managing complex landscapes. In The Sciences and Art of Adaptive Management: Innovating for Sustainable Agriculture and Natural Resource Management; Moore, K.M., Ed.; Soil and Water Conservation Society: Ankeny, IA, USA, 2009.

110. Berkes, F. Evolution of co-management: Role of knowledge generation, bridging organizations and social learning. J. Environ. Manag. 2009, 90, 1692-1702. [CrossRef] [PubMed] 
111. Plummer, R.; Crona, B.; Armitage, D.R.; Olsson, P.; Tengö, M.; Yudina, O. Adaptive comanagement: A systematic review and analysis. Ecol. Soc. 2012, 17, 11. [CrossRef]

112. Armitage, D. Building resilient livelihoods through adaptive co-management: The role of adaptive capacity. In Adaptive Co-Management: Collaboration, Learning, and Multi-Level Governance; Armitage, D., Berkes, F., Doubleday, N., Eds.; UBC Press: Vancouver, BC, Canada, 2007; pp. 62-82.

113. Cundill, G.; Thondhlana, G.; Sisitka, L.; Shackleton, S.; Blore, M. Land claims and the pursuit of co-management on four protected areas in South Africa. Land Use Policy 2013, 35, 171-178. [CrossRef]

114. Olsson, P.; Folke, C.; Hahn, T. Social-ecological transformation for ecosystem management: The development of adaptive co-management of a wetland landscape in southern Sweden. Ecol. Soc. 2004, 9, 2. [CrossRef]

115. Freeman, O.E.; Duguma, L.A.; Minang, P.A. Operationalizing the integrated landscape approach in practice. Ecol. Soc. 2015, 20, 24. [CrossRef]

116. Campbell, B.M.; Sayer, J. Integrated Natural Resource Management: Linking Productivity, the Environment and Development; CABI Publishing: Wallington, UK, 2003.

117. Milder, J.C.; Hart, A.K.; Dobie, P.; Minai, J.; Zaleski, C. Integrated landscape initiatives for African agriculture, development, and conservation: A region-wide assessment. World Dev. 2014, 54, 68-80. [CrossRef]

118. Palmer, C.G.; Biggs, R.; Cumming, G.S. Applied research for enhancing human well-being and environmental stewardship: Using complexity thinking in Southern Africa. Ecol. Soc. 2015, 20, 53. [CrossRef]

119. Cilliers, P. What can we learn from a theory of complexity? Emergence 2000, 2, 23-33. [CrossRef]

120. Cleaver, F.; de Koning, J. Furthering critical institutionalism. Int. J. Commons 2015, 9, 1-18. [CrossRef]

121. Lubell, M. Collaborative partnerships in complex institutional systems. Curr. Opin. Environ. Sustain. 2015, 12, 41-47. [CrossRef]

122. De Koning, J. Unpredictable outcomes in forestry-Governance institutions in practice. Soc. Nat. Resour. 2014, 27, 358-371. [CrossRef]

123. Grimble, R.; Wellard, K. Stakeholder methodologies in natural resource management: A review of principles, contexts, experiences and opportunities. Agric. Syst. 1997, 55, 173-193. [CrossRef]

124. Cleaver, F. Development through Bricolage: Rethinking Institutions for Natural Resource Management; Routledge: Oxon, UK, 2012.

125. Fabinyi, M.; Evans, L.; Foale, S.J. Social-ecological systems, social diversity, and power: Insights from anthropology and political ecology. Ecol. Soc. 2014, 19, 28. [CrossRef]

126. Liebrand, J. Methods for Researching Instittutions: Critical Institutional Perspectives. Environment, Politics and Development Working Paper Series Paper; Department of Geography, King's College London: London, UK, 2015.

127. Cote, M.; Nightingale, A.J. Resilience thinking meets social theory: Situating change in socio-ecological systems (SES) research. Prog. Hum. Geogr. 2011, 36, 475-489. [CrossRef]

128. Stone-Jovicich, S. Probing the interfaces between the social sciences and social-ecological resilience: Insights from integrative and hybrid perspectives in the social sciences. Ecol. Soc. 2015, 20, 25. [CrossRef]

129. Chan, K.M.A.; Balvanera, P.; Benessaiah, K.; Chapman, M.; Díaz, S.; Gómez-Baggethun, E.; Gould, R.; Hannahs, N.; Jax, K.; Klain, S.; et al. Why protect nature? Rethinking values and the environment. Proc. Natl. Acad. Sci. USA 2016, 113, 1462-1465. [CrossRef] [PubMed]

130. O'Brien, K.L. Do values subjectively define the limits to climate change adaptation? In Adapting to Climate Change: Thresholds, Values, Governance; Adger, W.N., Lorenzoni, I., O’Brien, K.L., Eds.; Cambridge University Press: New York, NY, USA, 2009; pp. 164-180.

131. Davidson, D.J. The applicability of the concept of resilience to social systems: Some sources of optimism and nagging doubts. Soc. Nat. Resour. 2010, 23, 1135-1149. [CrossRef]

132. Takeda, L.; Røpke, I. Power and contestation in collaborative ecosystem-based management: The case of Haida Gwaii. Ecol. Econ. 2010, 70, 178-188. [CrossRef]

133. Cheng, A.S.; Kruger, L.E.; Daniels, S.E. "Place" as an integrating concept in natural resource politics: Propositions for a social science research agenda. Soc. Nat. Resour. 2003, 16, 87-104. [CrossRef]

134. Ostrom, E. A general framework for analyzing sustainability of social-ecological systems. Science 2009, 325, 419-422. [CrossRef] [PubMed]

135. Van Oosten, C. Forest landscape restoration: Who decides? A governance approach to forest landscape restoration. Nat. Conserv. 2013, 1, 119-126. [CrossRef] 
136. Oxford University Press. English Oxford Living Dictionaries (Website). Available online: https://en. oxforddictionaries.com/ (accessed on 31 January 2018).

137. Leach, M.; Scoones, I.; Stirling, A. Dynamic Sustainabilities: Technology, Environment, Social Justice; Earthscan: London, UK, 2010.

138. Audouin, M.; Preiser, R.; Nienaber, S.; Downsborough, L.; Lanz, J.; Mavengahama, S. Exploring the implications of critical complexity for the study of social-ecological systems. Ecol. Soc. 2013, 18, 12. [CrossRef]

139. Karpouzoglou, T.; Dewulf, A.; Clark, J. Advancing adaptive governance of social-ecological systems through theoretical multiplicity. Environ. Sci. Policy 2016, 57, 1-9. [CrossRef]

140. West, S.; Haider, J.; Sinare, H.; Karpouzoglou, T. Beyond Divides: Prospects for Synergy between Resilience and Pathways Approaches to Sustainability; STEPS Working Paper 65; STEPS Centre: Brighton, UK, 2014.

2018 by the authors. Licensee MDPI, Basel, Switzerland. This article is an open access article distributed under the terms and conditions of the Creative Commons Attribution (CC BY) license (http://creativecommons.org/licenses/by/4.0/). 